Chair of Comparative Public Policy and Administration Department of Politics and Management University of Konstanz

Co-Managing Programme Implementation: Conceptualizing the European Commission's Role in Policy Execution Michael W. Bauer 


\section{Chair of Comparative Public Policy and Administration Department of Politics and Management \\ University of Konstanz}

Working Paper 03/2006

\section{Co-Managing Programme Implementation: Conceptualizing the European Commission's Role in Policy Execution}

Michael W. Bauer

Also published as:

Bauer, Michael W.: Co-Managing Programme Implementation: Conceptualizing the European

Commission's Role in Policy Execution, in: Journal of European Public Policy 13 (2006), 5, pp. 717-735

Konstanzer Online-Publikations-System (KOPS)

URL: http://www.ub.uni-konstanz.de/kops/volltexte/2008/6332/

URN: http://nbn-resolving.de/urn:nbn:de:bsz:352-opus-63322

\section{Contact}

Prof. Dr. Christoph Knill

Chair of Comparative Public Policy

and Administration

Box D 91

D-78457 Konstanz

Germany

Phone ++497531 885597

Fax ++ 497531882381

christoph.knill@uni-konstanz.de

University of Konstanz

www.uni-konstanz.de

Department of Politics and Management

www.uni-konstanz.de/sektionen/polver

Chair of Comparative Public Policy and Administration www.uni-konstanz.de/FuF/Verwiss/knill 


\title{
Co-Managing Programme Implementation: Conceptualising the European Commission's Role in Policy Execution
}

\author{
Dr. Michael W. Bauer, \\ Assistant Professor, \\ Chair of Comparative Public Policy and Administration, \\ Department of Politics and Management, \\ University of Konstanz
}

\begin{abstract}
The article offers a concept for better understanding the role of the European Commission during the implementation phase of European policies. The aim is to address a deficit within the literature about the European Commission and European public policy-making. While our knowledge about the Commission's ability to set the agenda and to influence decision taking has continuously advanced, we lag behind in understanding the Commission's behaviour in policy implementation. In order to focus the link between the European Commission and national policy implementation, this article proposes a mechanism that explains Commission behaviour throughout policy execution on the basis of resource interdependencies. More precisely, it argues that the Commission has an intrinsic motivation to overcome informational asymmetries during policy execution in order to stabilise its ordinary functions in policy drafting and decision taking. The central theoretical argument is thus based on the vulnerability of the Commission stemming from the fact that it has no formal say in national policy execution. On the other hand, its supranational peers, in particular the Council, Parliament and the Court of Auditors, hold the Commission responsible for implementation deficiencies. In order to diminish that dilemma-which occurs especially when European programmes stretch over repetitive policy cycles-the Commission needs what is called Implementation Management Capacity (IMC).
\end{abstract}

\section{Introduction}

This article is about the European Commission's role in policy implementation. The major question is how to conceptualise the link between the Commission and the execution of European policies. Therefore I introduce the concept of "implementation management capacity" (IMC). The aim is to provide a mechanism that explains Commission behaviour in the process of national programme implementation. The proposed explanation is based on the Commission's need to overcome informational asymmetries during policy execution in order to stabilise its ordinary functions in policy drafting and decision taking. The central theoretical argument is thus rooted in resource interdependence considerations that highlight the vulnerability of the Commission. This vulnerability stems from the fact that the Commission has no formal say in national policy execution but is (also) made responsible by other supranational institutions, i.e. by its European peers, in case of implementation deficiencies. In order to reduce threats resulting from this dilemma-which occur in 
particular when European programmes are implemented and reformulated over long periods of time in various policy cycles-the Commission seeks what is called Implementation Management Capacity (IMC).

The focus on the European Commission's role in policy implementation aims to close a gap in our understanding of European public policy. While there is no shortage of explanations for the Commission's dominant prerogatives, i.e. drafting legislation and facilitating European bargaining (Tsebelis/Kreppel 1998; From 2002; Majone 2002; Smith 2004; Dimitrakopoulos 2004; Schmidt 2000, 2004), efforts to theorise the Commission's role in post-decisional policy execution and management are still in their infancy (see however Puchala 1975; Jordan 1997; Tallberg 1999). ${ }^{1}$

Supranational involvement in national policy execution might soon draw more attention, since reasons which should lead students of European public policy to take the implementation challenge more seriously are numerous. First, after more than five decades of institutionalised European co-operation the scope of common policies is enormous. The European Union is currently engaged in virtually all areas usually related to state activity. Moreover, several distributive European policies have been in place for decades and one should expect the main organisation that drafted and re-drafted these policies to have a genuine interest in their national application (Tömmel 2003). Second, there is an increasing number of empirical cases where the Commission explicitly is assigned special, albeit often limited, implementation or managerial tasks. This is for example the case in competition policy, the preaccession programmes, environmental policy, or development aid. Third, and perhaps most tellingly, in recent years the Commission itself has launched several auto-reforming initiatives to help its services cope better with "the challenge of

\footnotetext{
${ }^{1}$ As early as 1975 Donald J. Puchala pointed to the need to better understand "post-decisional politics" in the European Communities (Puchala 1975: 497). The main difference between Puchala's account and the present argument is that he analyses transnational liberalisation issues and the noncompliance strategies of member states with respect to new initiatives of market liberalisation. In contrast, the focus of the present article lays on the implementation of spending programmes, i.e. on common efforts to establish positive integration. This is also the obvious difference with the more recent work by Tallberg $(1999 ; 2002 \mathrm{a}, \mathrm{b})$ or other students of compliance in the European Union (Lampinen, R./Uusikylä, P. 1998; Haas 1998; Börzel 2003; Franchino 2000). Within this debate, some authors are even interested in establishing propositions about different Commission strategies regarding non-compliance by member states (Mendrinou 1996). Although that goes some way into the direction of supranational supervision of national implementation, the focus of the overwhelming majority of the compliance research remains top-down and somewhat formalistic. More importantly, the interest of European level actors in correct implementation is taken for granted and not further questioned.
} 
managing the high degree of integration achieved by the Union" (Santer 1998; Peterson 1999: 55; Prodi 1999b, 2000; Spence 2000; Christiansen 2001). Recently, an internal reform has been adopted. Major concerns were to improve management skills and to focus the services on issues of policy execution (Kassim 2004; Christiansen/Gray 2004; Bauer 2006). So the post-decisional phase of EU policymaking and the function of the Commission therein, appear to be an area of increased concern to EU policy-makers. Although a systematic explanation of these phenomena has yet to be delivered, this article addresses the topic by focusing on the following questions: Why should we expect the Commission to be pulled into domestic policy execution? How are we to conceptualise the Commission's role as a co-manager of policy implementation? What are the effects of the Commission's involvement in post-decisional management issues for the process of European public policy?

To answer these questions this article proceeds in the following steps. Section two starts by shortly looking into classical implementation approaches and then turns to review the literature on the European Commission as an actor in EU policy-making in particular as regards policy implementation and management issues. It is concluded that these approaches cannot comprehensively explain our implementation puzzle. Section three lays the theoretical foundation for a new argument by referring to resource dependence theory and the concept of moral hazard in public policymaking. Section four presents the crucial relationships of the proposed Implementation Management Capacity (IMC) mechanism as derived from the theoretical discussion and thus opens ways for hypothesising and empirical testing. Section five provides the necessary background for assessing the usefulness of the IMC explanation in form of a case study on the implementation of structural funds in Germany. To round the picture, section six assesses the potential applicability of the IMC explanation in other policy areas. Finally, section seven sums up the findings and concludes on the utility of the IMC mechanism to helping to explain procedural change in EU policy-making.

\section{Reviewing the literature}

Studying implementation is the domain of policy-analysis and public administration (Ingram 1990). In the aftermath of the seminal study of Pressman and Wildavsky 
(1973) a vast amount of literature has emerged. We learned that, in particular in federal systems, policy objectives are a matter of political compromise and are therefore often vague. Policy execution is, for that reason, often unlikely to be (measurably) successful. Implementation often is a phase of creative reformulation and redesign of public programmes. Furthermore, many studies have pointed out that implementation may be improved by involving in policy formulation actors who later execute programmes. Studies of the implementation processes in federal systems like, for example, in the United States appear to be of particular interest for policy execution in the European Union (Derthick 1970, 1972; Pressman/Wildavsky 1973). A major empirical result of these research efforts has been to underline the condition of mutual dependence of actors at different levels of government. Many studies underline, in normative term, the tension between the fear of centralisation and the need for efficient and effective policy execution. For example, Martha Derthick has highlighted that "in giving grants and attaching conditions to them, the federal government becomes an actor in the state political system" (1970: 201). According to Derthick, the mechanism that made U.S. state actors comply is the "sharing of values", i.e. a kind of "indoctrination" (1970: 204). The sharing of implementation among levels is also a central theme of the Robert P. Stoker's work. He uses game theory to conceive implementation as a regime building exercise leading to a new kind of political equilibrium (1991: 105). Both Derthick and Stoker point to the fact that non-governmental actors, i.e. "clients" (Derthick 1970: 238) or "interest groups" (Stoker 1991: 105) are co-opted in the implementation process in order to boost or decrease the legitimacy of certain solutions. However, the major thrust of the research on implementation has been to specify the conditions for successful policy execution (Sabatier/Mazmanian 1979; Sabatier 1993). The debate about implementation gives without doubt useful hints for the research puzzle of this article. For example, the implementation game (Bardach 1977) is a multi-actor process in which participants attempt to foster or even improve their relative position with specific effects on problem solving capacity of the system and on centralisation tendencies (Scharpf/Reissert/Schnabel 1976; Stoker 1991; Sabatier 1993; Knill 2006). The point however is that this literature focuses on structures and processes. Much less attention is paid to conceptualising actor motivations. ${ }^{2}$ The classical policy

\footnotetext{
${ }^{2}$ The point here is that there is no reason to assume a priori that classical implementation concepts are better (or worse) than other approaches to conceptualise particular actor strategies (within
} 
implementation literature gives indeed little more than general hints on the specific question of why and how a relatively independent, central actor like the European Commission should be theoretically connected with policy execution, especially as it only has a very small resource base and its main task lies clearly in agenda-setting and in providing policy ideas.

It appears more promising to turn to concepts developed to depict the European Commission as a particular actor in EU public policy-making (Nugent 1997; Smith 2004; Dimitrakopoulos 2004). ${ }^{3}$ While the Commission's role in the post-decisional phase of EU policy-making as a "supervisor and overseer of front-line implementation" (Nugent 1994: 107) or as a "guardian of policy implementation" (Hooghe and Keating 1994: 388) has nominally been acknowledged, only a few articles up to now have addressed analytically the particular topic of the Commission's connection to policy implementation and management. ${ }^{4}$ Les Metcalfe was the first to warn about a "management deficit" stemming from a mismatch between the Commission's limited capacities and its increased policy responsibilities (1992, 1996, 2000, and 2001). Put simply, Metcalfe argued that the Commission has taken on more tasks than it can deliver and now has to create reliable management regimes. A new network style is also needed in order to manage policies across different levels of government and between ever more autonomous actors. When looking for remedies for the "management deficit" Metcalfe remains at an abstract, systemic level and thus gives little hint as to what exactly such managerial remedies would look like (Metcalfe 2001). Roger Levy (1997), on the other hand, describes and classifies-from a formal or almost legal perspective-the micro management functions of the Commission within policy execution. He finds that policy execution is increasingly shared between European and national actors. Since Levy bases his

accountability relationships and specific policy responsibilities) as regards the European policy making; these literatures just simply ask different questions. Hence, this short discussion shows that it is justified to turn to something else to inform our analysis.

${ }^{3}$ There have been few studies by students of European law that directly tackle important aspects of the "implementation of Community law" (From/Stava 1993; Duína 1997) that bear insight into the questions raised by the present article. In particular From and Stava point as early as 1993 to evidence for the existence of empirical phenomena that can be related to the concept of 'implementation management capacity' presented below. These authors do however show little interest in theory building and their accounts remain descriptive. Thus, although insightful, their work gives little orientation how to systematise the empirical information about implementation problems of EU programmes and regulation for theoretical argumentation.

${ }^{4}$ There are, however, quite a few articles on the related fields of execution, delegation and pressures for accountability pressure. See Christiansen 1997, Docksey and Williams 1994, Majone 2002; Pollack 1997.. Peters (1997) argument is based mainly on Metcalfe. 
analysis on the literature on the modernization of public administration (Levy 2003a, b), he comes to conclusions about administrative (in-)efficiency, but he does not theoretically address the relationship between the Commission and implementation. Brigid Laffan (1997) connects her diagnosis about the Commission's difficulties as a "policy implementer" with the growing EU budget and the rising pressure to assure its sound and efficient execution. Laffan thus identifies-in line with the approach developed below-an important relationship which increasingly pulls the Commission into the national execution of European programmes. However, she restricts her analysis to EU spending programmes and therefore does not investigate further into a theoretical explanation of more general applicability.

In sum, while looking at the problem from quite different angles, all the mentioned authors would probably agree that the Commission is becoming more present in implementation networks and increasingly attempts to safeguard the correct execution of European policies within the national political arenas. All three authors would almost certainly admit that the Commission's organisational culture is (still) biased towards producing ideas and that it lacks the necessary administrative resources to guard the proper implementation of EU policies in different national contexts (Noel 1973; Ludlow 1991; Nugent 1995; Schmidt 2000; Hooghe 2001; Egeberg 2003, 2004, 2005; Bauer 2005). While these analyses highlight the implementation or management gap, confine its boundaries, try to define its substance, and report observable changes and trends in insightful ways, a systematic explanation linking the Commission with policy implementation potentially applicable across all policy fields is not provided. The challenge lies in bridging the general concerns of implementation literature with the particular insights of the works on the Commission as a policy manager.

\section{The theoretical foundation of the implementation management explanation}

\subsection{Resource Dependence Theory}

I suggest that a revised version of the resource dependence theory (RDT) offers a basis for the conceptualisation of the European Commission's role within policy implementation. It also enables us to combine the interdependence concerns of classical implementation studies with the more specific expectations about the 
European Commission's management deficits in the European public policy process (Rhodes 1986b; Rhodes/Bache/George 1996: 382-383).

At the heart of RDT lies the assumption that actors, even corporate organisational actors, engage in welfare maximising strategies in much the same way as the common 'rational choice individual'. However, the individual aim of welfare maximisation is transformed within the interorganisational context to the ultimate institutional objective of safeguarding long-term organisational survival (Cyert and March 1992: 9).

RDT rejects pure structural approaches to organisational change by claiming that organisations not only react to external threats but may also lead to a pro-active strategy. Aldrich and Pfeffer argue "that organizations seek to manage or strategically adapt to their environments" (Aldrich and Pfeffer 1976: 79; Pfeffer 1982). At the very centre of RDT lies the finding that, "[...] organizations are not able to internally generate either all the resources or functions required to maintain themselves, and therefore organizations must enter into transactions and relations with elements in the environment that can supply the required resources and services" (Aldrich and Pfeffer 1976: 83).

Thus-and this has not yet been acknowledged in the literature-the crucial driving force behind organisational behaviour is the desire to acquire the needed resources in order to accomplish the task(s) assigned to them when created. This is simultaneously the best guarantee for survival and organisational stability. Put simply, "organizations engage in exchange because they need each other" (Laumann, Galaskiewicz and Marsden 1978: 470).

Organisations depend on elements in their environment; they need to interact, if they want to gain access to specific resources necessary to stabilise or enhance their positions. In short, they must interact if they are to survive. At the same time organisations can influence their environment, since they enjoy relative autonomy and are capable of developing and choosing the 'right' strategies for their survival. Whilst internal decision-making is influenced by environmental constraints, contingencies, and the anticipation of external actor behaviour, these do not determine it. RDT thus leaves room for opportunistic behaviour or "for the operation of strategic choice on the part of organizational members as they manoeuvre through 
known and unknown context" (Aldrich and Pfeffer 1976: 84).

Thus, in RDT the benefit-maximising individual of rational choice becomes an influencemaximising organisation, which interacts with other organisations, since it can no longer produce all the required goods internally. Inter-organisational coordination is the only way to produce the collective good, that is, a particular policy, whose supply is the justification, or even the raison d'être, of the organisation. Furthermore, only the effective delivery of the collective good will guarantee the necessary political support to ensure future organisational survival. In order to realise this objective, "[...] organisations attempt to absorb interdependence and uncertainty, either completely, as through merger, or partially, as through co-operation" (Aldrich and Pfeffer 1976: 87).

It is this interdependence, defined as "the reason why nothing comes out quite the way one wants it to" (Pfeffer and Salancik 1978: 40), that forces organisations to pool their resources, or economically speaking, to exchange them in a market. However, within this exchange of material and immaterial resources, organisations continually try to maximise their impact on policy outcomes. They are actually right to do so, because the more they are able to (re)internalise the production of the collective good (or, at least, control its diffusion), the less dependent and vulnerable they are to external threats of uncertainty.

Thus, in RDT perspective, the organisational struggle for survival implicitly entails a dynamic element, which can account for the expansive trends in actor behaviour. Once the unilateral production of a 'collective good' is excluded as a possible option, in theoretical terms, it is impossible to define a limit beyond which the struggling actor can be sure that his/his organisational survival is no longer under threat. For example, actors relying on weakly developed constitutional resources can never be sure that their resource base will withstand short-term, let alone mid-or long-term, power shifts in the network. Thus, given the basic environmental condition of uncertainty, the status quo cannot be regarded as a sufficient guarantee for longterm organisational survival. One key strategy to increase long-term survival security is therefore organisational expansion, i.e. expanding and acquiring new kinds of resources that may stabilize traditional functions (Cook 1977: 66-67; Pfeffer 1982: 193). 
In sum, the RDT considerations are founded on two very simple elements. In the first place, organisations are exposed to external constraints to which they have to respond. However, they can choose the response in accordance with opportunities and autonomously developed strategies. Second, the attempt to manage their external dependencies in order to ensure their long-term survival (or, from a shortterm perspective, to gain in autonomy) prompts organisations to follow a policy of expansion that reduces interdependence by diminishing dependence on external constraints (Pfeffer 1982: 193).

Thus, RDT enables us to conceptualise the Commission's link to policy implementation: the Commission's role as a formulator or developer of EU policies also depends on adequate policy implementation. In other words, poor implementation of EU policies constitutes a threat for the Commission. To minimise this threat, it is perfectly reasonable for the Commission, in RDT terms, to want to gain a hold on the national implementation of EU policies. Increasing with the 'age' of a policy or programme, one expects the Commission to become ever more sensitive to implementation issues and to be therefore increasingly pulled into national policy execution. The accumulation of control devices over the domestic execution of the supranational programmes hence becomes a self-protection reflex. However, on the basis of RDT one should expect the Commission to be interested and pulled into policy implementation only as long as its engagement stabilises its position within the cobweb of inter-organisational relations and responsibilities. The Commission is interested in policy implementation not as such but in order to safeguard its genuine position in drafting and agenda setting. Therefore, if a majority of peers or principals (or some key principles) object to its expansion into policy implementation-which becomes ever more likely with ever more intense involvement-the Commission will have to reassess the added value of its involvement in the implementation phase and may eventually be "forced" to reduce its oversight of policy execution.

\subsection{Moral Hazard}

RDT is powerful in conceptualising the general functionality of the relationship between organisational actors and their environment in the context of producing a public policy. It is, however, much less adept at specifying what kind of specific behaviour is to be expected. In order to generate testable hypotheses as regards the 
Commission's role in policy implementation, one needs to take into consideration the nature of the specific problems the Commission encounters in its relationship with policy execution. In essence, the Commission as a organisation that wants other actors, over which it has limited or no control, to execute something-in accordance with plans previously agreed upon-faces the classical problem of moral hazard (Blom-Hansen 2005).

Principal-agent theory has developed several mechanisms to counter moral hazard. ${ }^{5}$ Two parties having different but complementing resources at their disposal agree to work together, that is, usually the 'agent' on behalf of the 'principal', in order to realise common welfare gains which they could not achieve by pursuing individual strategies (Levinthal 1988: 155; McCubbins, Noll and Weingast 1989).

What remedy does the principal have to compensate for its structurally inferior position with respect to vital information on an agent's performance? In theoretical terms the answer is simple: enlarge your informational basis, or, as Holmström puts it, to "invest resources into monitoring [...] actions" (1979: 74; McCubbins, Noll and Weingast 1989: 434; Marks, Hooghe and Blank 1996: 355; Pollack 2003; Hix 2005).

In cases where the principal cannot mitigate informational asymmetries and conflicts of interests by resorting to hierarchical control, he or she needs an incentive structure in the form of "additional information systems" (Holmström 1979: 89) that induce the "agent to reveal as much of his privately held information as possible" (Moe 1984: 756).

However, we know that public policy-making as inter-organisational action comprises not only one agent and many principals (Marks, Hooghe and Blank 1996: 355), but a multitude of principals confronted by various agents who may contribute in different modes and qualities to the making of a particular policy. ${ }^{6}$ Bearing this in mind, we can deduce another strategy to help the principal control moral hazard: that of exploiting competition among agents in order to gain performance control.

In economic theory, exploiting agent competition is seen as being relatively easy, on

\footnotetext{
${ }^{5}$ Note that it is not the Principle-Agent Theory and the question of delegation that is of concern here but only the recommendations developed by this literature to alleviate the problem of moral hazard.

${ }^{6}$ See also Tallberg 1999 who models the complexity of relationships between various principals and agents by introducing the new role of a supervisor.
} 
the condition that the tasks the agents are hired for are not too specific. Thus, in cases where the principal is unable to investigate agents' day-to-day performance (because it is either impossible or too costly) the principal should employ two (or more) agents to do the same job. This allows the principal to benchmark the 'productivity' of an individual agent by comparing their achievements with the performance of the sample. Unfortunately, in bureaucratic politics this solution must be excluded, since one rarely finds different agencies doing the same job on a specific territory and at the same time (Moe 1984: 762). However, there are usually other 'interested' (societal or public) actors which can be used as 'fire alarms' (McCubbins and Schwartz 1984; McCubbins, Noll and Weingast 1989; see also From and Stava 1993: 63) and serve political principals in a similar way as a multitude of economic agents executing the same job for an economic principal. These 'fire alarm' or 'watchdog' actors do not necessarily need to dispose of farreaching resources; it is sufficient that they are in some way interested in or affected by the policy in question. These actors often try to become involved because they have specific regulatory or redistributive aims. In any case, a strategy of this sort pursued in bureaucratic politics will generate a deliberate increase in the number of societal actors involved in public policy-making (Stoker 1991: 105).

In summary, even though many of the economic theory propositions for coping with the moral hazard problem in principal-agent relations, such as the optimisation of payment schemes or a more careful selection of the agents, are not applicable in bureaucratic politics, there are two basic strategies which can be used to reduce the risk of moral hazard in the sphere of public policy. The first, and most general one, is the development of additional information systems of whatever kind that monitor policy processes and assess policy outcomes. The second strategy is the expansion of participation in order to explore political support and added-value in terms of close third party supervision of the agent's performance, otherwise too costly or, because of constitutional constraints, simply beyond the reach of a bureaucratic principal like, for example, the European Commission (Egeberg 2005; Derthick 1970: 8).

\section{The mechanism: implementation management capacity}

To successfully accomplish its usual habitual tasks as a policy entrepreneur, the Commission depends upon its environment, i.e. other organisations like the Council, 
the European Parliament, the Court of Auditors as well as national or regional governmental actors. In this context, involvement in and information about the execution of EU policies are of crucial importance, because such information can help the Commission to improve agenda setting and policy drafting, thereby parrying accountability pressures from its European peers. I call the Commission's ability to institutionalise and exploit supranational linkages with policy execution in terms of supervision, information and participation 'implementation management capacity' (IMC). Besides, I expect, next to attempts of the Commission to seek direct presence in implementation networks the Commission to try to co-opt interested third parties (i.e. gender and environmental groups, economic and social partners) depending on the particular differences between supranational and national policy objectives. For the Commission these societal actors function as 'fire-alarms' to detect national deviation from supranational implementation plans. There should be extensive reporting duties and supervisory as well as 'objective' devices for programme evaluation. The European Parliament and the Court of Auditors represent organisations that are primarily interested in the quality of supranational policy outcomes. They will take the Commission into account for policy outcomes and therefore compel it to enter policy implementation, if it wants to deliver policy programmes of high quality (on which its organisational survival depends upon in the long run). The IMC model conceives the structure of actor interaction in terms of a double principal-agent relationship. The Commission is the agent as regards programme production at European level. Since this programme production does not take place in a vacuum, the Commission becomes-in particular when various policy cycles are run through-ever more dependent upon the efficiency of national policy implementation. Because of the European level expectations of its peers, it thus assumes the role of a principle of the national execution of supranational policies. IMC thus conceptualises actor relationships in two important respects. First, it sheds some light why and when the Commission is expected to be ever more concerned with national policy implementation. Second, it suggests what kind of procedural changes we should expect as an indication for growing supranational involvement in national policy implementation, namely more institutionalised information channels and the co-optation of interested third parties into implementation networks. In the following section, an account of the implementation of European structural funds in Germany serves as an empirical testing ground for the developed IMC model. 


\section{Case study: EU structural funds in Germany}

The structural funds are the main instruments of European regional policy. One third of the European Union's budget is spent on programmes for struggling regions and on initiatives to adapt regional work forces. The structural policy is one of the oldest European policies. Although it has undergone huge changes, its origins can be traced back to the 1960s. It is now about to complete its third programming cycle after a thorough reform in 1988. I have selected structural funds implementation in Germany as a case study for assessing the IMC model for various reasons. First, there is variance as regards the dependence of the German regions upon EU funding. Thus authorities cannot be said to be per se in favour of EU intervention and thus more positive about the Commission's role in implementation like in a generally poorer member state. Second, its administration is generally respected in professional terms, so it cannot be argued that administrators have no choice other than to comply with European level provisions because of lacking national or regional capacities. Finally, since Germany is a founding member of the EU, one cannot claim that observable effects are to be explained by general unfamiliarity with European practices or particular lack of experience in coping with the EU structural funds in particular. If effects of a changing role of the Commission can be detected when studying the implementation of structural funds in Germany, i.e. under by and large unfavourable conditions, one has a strong argument that such effects can also be expected in other environments.

\subsection{Peer Pressure at European Level}

In the second half of the 1980s a central aim of the EC was to achieve a true internal market (Delors 1987; Commission 1988). Negative side effects of the completion of the internal market to (mostly) southern economies would be compensated for by financial redistribution from north to south via a reform (and financial expansion) of the structural funds. The 1988 reform of the EC structural policy however not only increased the budget of the funds to an unprecedented level but it "Europeanized" the policy content as well as its administrative procedures (Allen 2000; Hooghe 1996a; Bache 1999). The evolving EC model of a European structural policy and the higher financial resources invested meant that the Commission would be taken into account for the success of that policy in terms of sound spending and European 
added-value (Delors to the EP, 1987: 30).

The new mechanism for planning and implementing EC structural policy was called 'partnership'. Next to the other catchy innovations such as 'concentration' (on target zones), 'additionality' (EU funding was to supplement, not replace national development aid) and 'programming' (pluri-annual programmes instead of one-shot projects), 'partnership' did not just have a managerial meaning, it was presented by the Commission as the guiding principle of the whole reform undertaking - not least of all since it was meant to apply to all stages of the policy-making process, i.e. the preparation, financing, monitoring and assessment (Commission 1988; Bauer 2002).

Article 4 of the 1988 framework regulation defined 'partnership' as "close consultations between the Commission, the Member State concerned and the competent authorities designated by the latter at the national, regional, local or other level, with each party acting as a partner in pursuit of a common goal." In practice, 'partnership' established an administrative process whereby the involved public authorities (and later other societal actors) at the various levels worked out regional development plans ('community support frameworks'), operationalised them (in 'operational programmes') and monitored their implementation (in special committees). One additional feature of the reform was the requirement for mid-term and ex-post evaluation and ongoing monitoring of the Community's structural action (Council 1993).

In 1993 the first grand revision of the new planning and implementation mode took place. As regards the implementation procedures, 1993 meant a consolidation of the EC/EU model from 1988. Reporting duties were enhanced, monitoring and evaluation requirement clarified and expanded and the demands for the inclusion of economic and social partner, in the planning as well as in the implementation process leaves little doubt that the Commission tried to enhance its link with the execution phase of structural funds. The success of that policy was however ambiguous: as the documents on the implementation of the structural funds and the cohesion reports show, there was great variety as to how the EC/EU regulations were applied in the various national arenas. That means that there was certainly no systematic added-value of European-level steering capacity in structural policy.

In this phase of the reformed structural policy, the Court of Auditors and the 
European Parliament followed closely the planning and implementation of the structural funds, calling upon the Commission to fight fraudulent practice and to improve its implementation system and guarantee (and demonstrate!) good value for EU money (Court of Auditors 1992, 1993). The European Parliament, whose decisional powers in structural policy were limited, demanded sound and efficient execution and greater commitment that the European objectives of the structural funds would be achieved. The Parliament also supported what can be called the "societal opening" of the structural funds planning and implementation procedures, by asking for the inclusion of social and economic partners and later pushing also for the participation of environmental, gender and consumer interests in the policy networks.

The Council, however, was in crucial respects split over the EU structural policy. First, the net-payers had a natural interest in information about how and with what effect the net-receivers would spend EU money in structural policy. Supporting monitoring and evaluation as cross-national supervision instruments in other countries, argumentative consistency required the acceptance of systematic evaluation also at one's own territory, since, "[o]ne cannot demand explanations about the whereabouts of every penny spent by 'the others', and [at the same time] ask for flexible and 'unbureaucratic' financial support from Brussels" (Wulf-Mathies 1995c). Second, social democratic governments were more in favour of the idea of including the social and economic partners in the planning and implementation process than conservative governments. At the beginning of the second funding period, enthusiasm for social and economic partners was generally low: "The member states seem to hide behind the shield of the subsidiarity principle their wanting to exclude the Commission from the execution of the structural funds. [...] Subsidiarity as a guiding principle for the Union means, as I understand it, above all transparency and participation; and I will therefore especially support the closer involvement of the regional and local authorities and the social partners in programme planning and implementation' (Wulf-Mathies 1995a). Eventually, towards the end of the 1993-1999 funding period, social and economic partners were involved in the structural policy process almost everywhere according to national standard procedures (Bauer 2001).

Hence, the first funding period (1988-1992) was coined by experimenting with the new rules and procedures. Since the whole policy was new, neither the Commission 
nor the various national authorities involved would take evaluation and management issues terribly seriously. This changed in the 1993-1999 period. From 1993 onwards, the Commission stressed much more the need of national and regional authorities to comply with EU concepts and priorities also when executing the programmes. Evaluation and monitoring, reporting duties as well as the fair inclusion of organised interests was taken much more seriously and thus the pressure for national and subnational authorities increased. As a "response" the resistance to the "overbureaucratic" and "expansive" behaviour of the Commission grew-especially towards the end of the second supportive period when the opportunity to revise the regulatory basis of the policy opened (Bauer 2002).

In the academic literature there is much disagreement about whether and to what extent the 1993 and 1999 revisions of the structural funds regulations actually increased or diminished the role of the European Commission and whether one can speak of a re-nationalisation of the EU structural policy-making towards the turn of the century (Marks 1993; Hooghe and Keating 1994; Pollack 1995; Allen 2000; Hooghe 1996a, 1996b; Sutcliffe 2000; Hooghe and Marks 2001). While empirical evidence for an intergovernmental "clawing back" of competences is scarce (Bache 1999), there are indications that during the 2000-2006 funding period, the Commission has tried to keep a low profile as regards national implementation allowing for more flexible and decentralized execution. At any rate, rather than omitting the Commission from policy implementation, the 1999 revisions seemed to have streamlined administrative procedures and clarified competences (Bauer 2001). At present, i.e. towards the end of the third funding period and with first suggestions of the Commission how to re-organise structural policy in view of enlargement on the table, there are signs that the Commission indeed keeps on following this path.

In sum, the structural funds have been a sort of side payment to losers of economic liberalisation. The growing financial resources involved and the increasing attempts to shape structural policy according to European priorities increased calls for valuefor-money and assurances of correct national policy implementation. The Commission developed a genuine interest in sound policy planning and implementation. However, it faced contradicting demands from supranational (Court of Auditors, European Parliament, parts from the Council) and national actors (national and regional governments) with respect to the supervision and monitoring of 
the implementation process. The Court of Auditors and the Parliament demanded a greater informational basis, better cross-national comparison and scientific proof of the "success" of the EC/EU engagement. By partly responding to these demands the Commission fine-tuned evaluation and monitoring, increased reporting and auditing duties and invited interested parties to participate in implementation networks. This, in turn, led to rising national and regional opposition to the EU implementation model and provoked complaints about the burdensome and bureaucratic ways in which EU structural funding is administered. Answering to these mounting pressures, the Commission softened up implementation procedures accordingly. Now, in view of the next funding period (20072013) the Commission is calling for even more "flexibility" and "subsidiarity" (Commission 2005).

\subsection{The National and Sub-National Level}

The implementation management capacity (IMC) model expects that the Commission can make strategic choices according to what it perceives as supporting and stabilizing its resource bases and therefore strengthening it position in the cobweb of inter-organizational relations. It was supposed that at European level the Commission faces contradictory demands from its peers (Christiansen 1997)—as regards the intensity of its involvement in the management of policy implementation. Illustrative evidence has been given above supporting the thesis that the crucial "resources" connecting the Commission with the national policy execution phase (evaluation/monitoring and reporting/auditing as well as the proliferation of interested actors) have been critical issues in the debates about the application of European structural policy. On the basis of expert interviews (mainly with German structural fund implementers), this section examines whether there is empirical evidence indicating that IMC expectations are corroborated in reality. The crucial question is whether IMC-related resources have indeed been sought and used by the Commission to strengthen its connection to national and regional policy evaluation in order to improve its genuine position in policy drafting and planning in the network.

Evaluation and monitoring ${ }^{7}$ : Prior to 1989 systematic monitoring of program execution and evaluation of the results were alien to the German administrative

\footnotetext{
${ }^{7}$ I will distinguish between "monitoring" and "reporting and auditing" for reasons of convenience. In the IMC model, as elaborated above, these two strategies are both ways of increasing informational links with the implementation arena.
} 
system in general and for regional economic development policy in particular. National and regional officials before and during implementation were sceptical of such instruments and regularly expressed doubts about whether the "huge efforts" expected from them in the implementation of EU structural policy would actually pay off. Additionally, evaluation results were seen as adding information to European level policy-makers; at national and regional level these results could be anticipated. National and regional actors might not have been keen to give additional information to the Commission. Evaluation as such was seen as over-taxing and bureaucratic; adding much to the Commission's understanding but offered little added-value for implementers. "Evaluation is very confusing; it's very comprehensive, very complicated and it's difficult to comply with all these rules. [...] We have a framework regulation, a coordination regulation; we have the ESF, the ERDF and the EAGGF regulation. Then, there are the SEM 2000 and the 2064/97 regulations. $^{8}$ If I really wanted to comply with all that, I could stop doing my normal job" (interview). ${ }^{9}$ A "nonpaper" of the German federal government even suggested that "all that money that is to be spent on evaluation-which most likely nobody will read-should be given to the target groups of the structural funds objectives instead" (Bundesregierung 1998: 13). There has been the clear feeling that the Commission uses evaluation to "its own" advantage.

\begin{abstract}
"[...] with evaluation the Commission also attempts to gain influence. It's able to say, 'listen, your report shows this and that and this isn't as it should be. We expect you to adopt the appropriate measures to change your course'. [...] Eventually if new programmes for the following support period have to be set up, the Commission is going to fall back on its evaluation knowledge and it will try to use it in its own interest, i.e. it will back up its arguments for increasing or decreasing the financial volume of particular priorities. So far evaluation is highly interesting for the Commission. Not because evaluation was an instrument of 'enlightenment' [...]. But evaluation gives the Commission [...] the possibility to put the pressure on. It is the details that are most tricky." (Interview)
\end{abstract}

This reading is also supported by the Commission itself:

"Evaluation is most useful for us here in Brussels, since we are further away from the

\footnotetext{
${ }^{8}$ SEM stands for "Sound and Efficient Management" iniative launched by Jacques Santer. The 2064/97 Commission regulation requires additional auditing procedures where European co-financing is involved in national programmes.

${ }^{9}$ The empirical evidence reported here has been collected in various expert interviews at German regional (Hessen, Rheinland-Pfalz, Thüringen, Sachsen-Anhalt) and national (Bundeswirtschafts-und Sozialministerien) as well as at European level (mainly Commission) in 1997/98. A second wave of interviews was conducted (mostly) with the same people at the German regional level in spring 2004. The interviews were held in German and English; German quotations have been translated by the author.
} 
actual implementation [...] and we do not have the 'feeling' about what exactly goes on there. With evaluation we get access to information from which we are usually cut off. Especially since we are not always on the same mental [...] 'wavelength' with the national administrations - which often creates a kind of information filter in our relations to them. For improving our programme conceptions and programme steering evaluation proved to be of a very particular value. They are far from telling us everything." (Interview; emphasis added)

Reporting and auditing: In the area of reporting and auditing the regional or national implementers of EU structural funds have to collect (usually quantitative) indicators and report them about four times a year to the Commission. Moreover, together with the European co-funding, special auditing schemes come about that also are regularly reported to Brussels. As regards these reporting and auditing duties in the context of EU structural funding the national and regional concerns are very similar to those about evaluation and monitoring on the whole. The additional required informational duties are seen as overly burdensome, bureaucratic and little "helpful" in the daily work of the implementers.

\begin{abstract}
"The quantitative monitoring indicators, as they are required by the Commission, can be seen as an honour for any central command economy. It is more than questionable whether the required indicators are available at all or whether they could be gathered by investing reasonable effort. [...] The Commission intervenes massively in the implementation power of the Member States; instead of increasing decentralised decision competence, it is limited." (Bundesregierung 1998: 12)

"With respect to the reporting duties, or rather, reporting absurdity, I have the impression that we are permanently producing reports. There are the 'last-tranche' reports, the annual reports, the reports that have to be attached to the requests for changing the implementation priorities in order to re-allocated not used EU funding. [...] One is usually not able to allocate the money for five or six years exactly, so there are a lot of requests for such changes. [...] And moreover, each time the monitoring committee meets, that is, once every six months, we have to report about the 'state of the art'." (Interview)
\end{abstract}

In the face of such complaints and misgivings it comes as no surprise that sometimes the mutual suspicions appear not to have led to better information at European level but to decreasing information flows. In any case, the mistrust among the involved partners at regional/national and European level grew exactly at that time when the Commission started to take seriously the evaluation and reporting duties as laid down in the regulations.

"The Commission tried in the starting-phase [of the 1994-1999 period] to pressure the federal level and the Länder governments to deliver certain information. [...] This led to even greater reluctance on the part of the Länder and the Bund, which in turn prevented any open information policy between them and the Commission. [...] Sometimes what took place at the monitoring committee meetings was almost absurd since the German administration played 'hide-and-seek' with the Commission. The Commission wanted 
some data and they [the German authorities] were not willing to hand it over-even though they actually had this data [...]. Certainly, it was never really clear why the Commission would now need exactly these numbers. However, the situation was that they would almost play theatre before each other." (Interview) ${ }^{10}$

Watchdogs and fire-alarms: There is an apparent informational incentive for the European Commission to cooperate with "affected actors" that have an intimate regional and local knowledge and different interests than the national public authorities. In the words of a regional trade unionist: “The Commission doesn't know what's going on deep down below. [...] And because the Commission lacks information about the situation on-the-spot it tries to get it by involving as many people as possible. That's how the Commission gets information about what's going on at regional and local levels. [...] The Commission would be completely helpless without the feedback from the economic and social partners" (interview). We know from studying the discussions at European level in the context of revising the structural funds implementation mode that the idea of including affected third parties has not always come from the Commission, or more precisely from the DG for regional policy. The European Parliament and the DG of Social Policy could be identified as the central supportive actors, especially in the case of including gender, environment and consumer groups into the implementation networks. This, however, does not inhibit the Commission from making use of that new resource in an advantageous way. As regards the role of trade unions as central social partners with whom regional structural and social policy was to be coordinated in the monitoring committees, there have been reports of "direct contacts" exactly in the way one would expect on the basis of the "fire-alarm" concept. A regional trade union official reported that he could elicit Commission support for broadening the scope of regional support priorities in the direction of EU concepts (which happened to coincide with the organisational interest of the trade union in question) against the preference of the regional government by indicating the issue contested in the regional political arena to the European Commission.

"And Mr ... [senior official in DG XVI] always has an open ear for our complaints. [...] And after examining our paper he encouraged us to approach him later, because he interpreted the situation similarly and seemed convinced he would be able to support our positions. [...] This provoked quite a bit of irritation in the economic ministry, since we suddenly seemed to be closer to the Commission's position than they were." (interview)

\footnotetext{
${ }^{10}$ This quotation concerns the beginning of the 1994-1999 funding period.
} 
The societal interest groups see their role and their relationship with the Commission in providing additional information independently of regional and national governments: ${ }^{11}$

"[The Commission's interest in social partner participation] is certainly not driven by pure altruism [...]. I think this is also a question of power ['Machtfrage']. If one is able to approach the regional governments through the federal level, and can put pressure on regional governments through regional interest organisations-as a counterweight to the administration - then this certainly serves the interests of the Commission." (interview; emphasis added) $)^{12}$

Interesting is also the inherent potential of including ever more societal groups as affected third parties in shifting indirectly the distributional impetus:

\begin{abstract}
"If I include more players in a co-ordination process, this is going to increase the hurdle to reach a consensus. [...] Suppose the Commission wanted, among other things, to maximise its influence. Then it could make selective use of certain arguments raised by particular interest groups. This would help it push for certain decisions. Let's take 'sustainability' as an example. If environmental interests are particularly strongly represented and the Commission wants to push for 'sustainability' then it might stress those arguments. [...] This can certainly be applied as an instrument to justify and to pressure for certain decisions." (interview)
\end{abstract}

The proliferation of societal actors seem to have occasionally helped and does potentially support the Commission in reducing informational and supervisional gaps as regards policy implementation. It may even open opportunities for shifting programme priorities in a certain direction (as in the example towards "sustainability"), thus helping to overcome opposition from regional implementers if need be. As a Commission official described, it helps ...

[...] to know what people think on the ground-not only the local authorities but also the social partners. And there is an upstream from the local level partners, to their national and European level representatives and then it comes to us here [...] because the authorities see the problems from their point of view and the same problem is not described in the same way by the social partners. So, we can mix both and have a better understanding of the problems on the ground. (interview)

\footnotetext{
${ }^{11}$ This, of course, is not a one way approach: "Moreover, in recent years, it has been pointed out that the institutionalisation of partnership, and thus the quality of co-operation, has made some progress, and that the inclusion of the social partners was in the interest of the administration because, on the one side we give them information, but on the other we also get information from the social partners, and that's why we think partnership has great potential value for us. Because our information increases the acceptance for the instruments used, it reduces misunderstanding, and at the same time we get to know what they want and what they need" (interview).

${ }^{12}$ Or as Marc E. Smyrl (in the context of the Integrated Mediterranean Programmes) put it, "in a direct dialogue with the Member States, the Commission was bound to come out second best. Increasing the number of participants was one way to redress the balance" (Smyrl 1998: 93; see also KohlerKoch 1998a: 24).
} 


\section{Applicability in other policy fields}

The reported empirical evidence should not let us jump to sweeping conclusions. There are some caveats. First, it is only taken from one country example, namely Germany (although various units at regional level have been studied). Second, the IMC model has been developed going back and forth from empirical data to analytical explanation.

The critical question, then, is whether the IMC model can merely elucidate the implementation of structural funds or whether it can be applied to other EU policies. Its explanatory value certainly applies best where EU financial resources are distributed and spent by member state authorities on behalf of the European Union. Hence, in principal, apart from structural and cohesion policy IMC may be of use in agriculture, social policy, development aid and research policy, i.e. either distributive or redistributive policies. There is no reason why the underlying mechanisms identified should not apply to the logic of European regulatory policies. Be it in environmental, health or education, i.e. policy areas where competences are shared and objectives are commonly agreed upon but implemented by national actors, the Commission's position in agenda-setting and formulation also depends on a valid link to policy implementation. The longer the policy "lives", i.e. the more policy cycles have to be planned, agreed upon and implemented, the more it depends on this link.

Looking more closely at European environmental policy, for example, there is clear evidence that the incorporation of societal actors in policy implementation has been driven by concerns of lacking supervision resources and growing informational needs at supranational level in the sense depicted by the IMC argumentation (Holzinger/Knill/Schäfer 2003; Lenschow 1999; Knill 2000; Knill/Lenschow 2000). This is also the case regarding the implementation of European social policy: the general problem of the information deficit and how the Commission attempts to tackle it also resembles the considerations of the IMC framework (Falkner et al. 2004; Cram 1993). The areas of competition policy and state aid seem to be other cases in point (Smith 1997; 1998). "Information is an important element for improving implementation. If the Commission gets precise and coherent feedback on how EC law and programmes are practised in the member states, it has something to work on. If feedback is lacking or poor, other measures and improvements will be difficult to achieve" (From/Stava 1993: 59). Unfortunately, there is no space here to examine 
particular European public policies more thoroughly. This brief examination of other empirical literature make the conceptualisation of actor interaction during European policy implementation according to the IMC mechanism plausible. Additionally, the Commission itself has recently suggested how the "implementation of certain EC policies could be better achieved" (European Commission 2001: 13). A new instrument, i.e. the "tripartite contract" is supposed to set up monitoring and assessment links to programme implementation and thus comes close to the IMC mechanism. Although such contracts have not yet played a significant role in practice, further research on the lines suggested by this article appears promising. ${ }^{13}$ At any rate, since the Commission seems to pay ever more attention to issues of national policy implementation, IMC may prove to be a valuable analytical device to improve our understanding of processes and the structure of actor relationships in various European policy fields.

\section{Conclusion}

The aim of this article was to offer a theory-based conceptualisation of the link of the European Commission with the implementation of European policies. On the basis of resource dependence theory (RDT), it was suggested that the Commission actually needs to get involved in the national implementation of European policies, in order to stabilize its position in agenda-setting and program drafting within a highly uncertain political environment. Seen from the perspective of a double principal-agent relationship, a moral hazard problem lies at the centre of the Commission's implementation challenge, i.e. that national policy implementation is conducted by autonomous national and regional actors with only insufficient and patchy connections to the supranational level. The literature suggests several instruments for reducing the risk of moral hazard by keeping in check "shirking agents". Institutionalising information channels (policy evaluation, reporting duties etc.) and the cooptation of interested third parties into the implementation networks have been identified as tools which-in principle-appear to be transferable from the economic sphere to the making of public policies. Theoretical explanations (lacking resources and informational needs) and empirical expectations (about the quality of likely

\footnotetext{
${ }^{13}$ The first ever "tripartite Agreement" was signed in October 2004 between the Commission, the Italian Government and the Lombardy Region. Monitoring, transparency and assessment play a major
} 
procedural changes) have been combined within the model of implementation management capacity (IMC). Evidence taken from the making and implementation of the structural funds in Germany has supported the thesis that supranational actor behaviour and procedural change can be detected as expected on the basis of the developed IMC mechanism. It appears very plausible that the IMC model is able to explain actor relationships and interdependencies, thus predicting procedural change, also within other areas of European policy implementation. The secondary analysis of empirical accounts of environmental policy, social policy or the internal market suggested that IMC may be a useful tool for further empirical research on the implementation of European public policies. To facilitate critical empirical testing of the IMC explanation, I conclude by pointing out major implications of the model on the basis of the following hypotheses.

(1) The Commission's involvement in policy implementation will increase, the older a European policy becomes and the more often a policy is redrafted, i.e. the more often it went through the policy cycle. If the policy consists of direct European co-financing of nationally executed programs, this should additionally lead the Commission to seek direct information about and involvement in policy implementation.

(2) The longer a particular European programme runs, and the greater the input of resources from the European level, the higher the demands of European level actors on the Commission to provide detailed information about national execution and to take co-responsibility for efficient policy implementation.

(3) This threat of being held accountable (by European peers) for implementation deficiencies together with the need for continuous and detailed knowledge about national policy implementation (to satisfy peer pressure and to optimize policy drafting), forces the Commission to seek informational access to the implementation arena. Given its limited organizational resources, the Commission will therefore attempt to institutionalise direct feedback channels (policy evaluation, reporting duties etc.) and to include interested third parties (as "fire alarms") to satisfy its information needs and to check on national and regional governmental actors. Thus, the supranational involvement in policy execution in terms of supervision, feedback

role in this document. Cf. http://europa.eu.int/comm/governance/docs/texte_convention_ tripartite_en.pdf. 
and participation will lead to a specific form of procedural change which should be characterized by the widening of the circle of non-governmental actors involved in implementation and the set up of regular informational channels from the national implementation arenas to the European level.

(4) The new requirements expected from national and regional actors that come along with these changes are easily depicted as supranational usurpation of competences as well as proofs for bureaucratization and red-tape. The need for the Commission to remain connected with the execution and management of European programmes thus allows actors on lower echelons to politically exploit the situation and to de-legitimise European policy solutions.

In its attempt to decrease its resource dependency and to stabilise its position in the policy process, the European Commission is therefore likely to pave the way for the unintended politicization of European policy implementation. This, in turn, dissolves the Commission's very basis for acceptance within national implementation, i.e. its claim to apolitical expertise. There is no easy escape from this dilemma. Given the lack of sanctions against defecting national governments, the major hope for the European actors (as a group) is to pressure the European Commission-the only European institution that somewhat resembles a supranational executive agency and that has a particular interest in the "success" of the European programmes, the drafting of which is its prime responsibility. The Commission, on the other hand, cannot remain indifferent to what happens to European policies when they are implemented in national arenas. The Commission's dependence on the results of implementation action by quasi autonomous actors on a lower level of government appears to be the unique feature of the European policy process. The European Commission does not seek implementation authority for its own sake but it needs information about programme execution to legitimise European efforts and to be able to deliver acceptable policy drafts. 


\section{Acknowledgements}

I thank Christoph Knill for comments. I am grateful to Elise Hadman for her support as regards conducting the expert interviews. For language corrections I thank Michael Dobbins and (again) Elise Hadman. The usual disclaimer applies.

The empirical part of this article draws on more than 40 extensive expert interviews conducted between 1997 and 2004 in Brussels, Bonn, Berlin and various regional capitals of Germany. Most interviewees were either European Commission officials or national civil servants responsible for regional and structural policy. I am deeply indebted to these interview partners many of whom even agreed to be interviewed more than once. Further information about the interviews can be obtained by asking the author 


\section{References}

Aldrich, H. E. (1976) 'Resource Dependence and Interorganizational Relations', Administration and Society 7(4): 419-55.

Aldrich, H. E. and Pfeffer, P. (1976) 'Environments of Organizations', Annual Review of Sociology 2: 79-105.

Allen, D. (2000) 'Cohesion and Structural Funds: Transfers and Trade-Offs', in H. Wallace and W. Wallace (eds.), Policy-Making in the European Union, Oxford: Oxford University Press, pp. 243-265.

Bache, I. (1999) 'The Extended Gatekeeper: Central Government and the Implementation of EC Regional Policy in the UK', Journal of European Public Policy 6(1): 28-45.

Bardach, E. (1977) The Implementation Game, MIT Press, Cambridge: Massachussetts.

Bauer, M.W. (2006) 'Die Reform der Europäischen Kommission: Eine Studie zur Managementmodernisierung internationaler Organisationen', Verwaltungsarchiv. Zeitschrift für Verwaltungslehre, Verwaltungsrecht und Verwaltungspolitik, 97(3): 35-60.

Bauer, M.W. (2005) 'The European Commission', in P. van der Hoek (ed.), Handbook of Public Administration and Policy in the European Union, Public Administration and Public Policy 113, Boca Rota, London, New York: Taylor \& Francis, pp. 149-176.

Bauer, M.W. (2002) 'The EU 'Partnership Principle': Still a Sustainable Governance Device Across Multiple Administrative Arenas?', Public Administration 80(4): 769-789.

Bauer, M. W. (2001) A Creeping Transformation? The European Commission and the Management of EU Structural Funds in Germany, Dordrecht: Kluwer Academic Publishers, Library of Public Policy and Public Administration.

Blom-Hansen, J. (2005) 'Principals, Agents, and the Implementation of EU cohesion policy', Journal of European Public Policy 12(4): 624-648.

Börzel, T. A. (2003) 'Guarding the Treaty: The Compliance Strategies of the European Commission', in: T. A. Börzel and R. A. Cichowski (eds.), The State of the European Union, 6, Law, Politics, and Society, Oxford: Oxford University Press.

Cook, K. S. (1977) 'Exchange and Power in Networks of Interorganizational Relations', Sociological Quarterly 18(1): 62-82.

Cram, L. (1993) 'Calling the Tune Without Paying the Piper? Social Policy Regulation: The Role of the Commission in European Community Social Policy', Policy and Politics 21(1): 135-46.

Christiansen, T. (1997) 'Tensions of European Governance: Politicized Bureaucracy and Multiple Accountability in the European Commission', Journal of European Public Policy 4(1): 73-90.

Christiansen, T. (2001) 'The European Commission: Administration in Turbulent Times', in: J. Richardson (ed.), European Union: Power and Policymaking, 2nd edn. London: Routledge, pp. 95-114.

Christiansen, T. and Gray, M. (2004) 'The European Commission in a Period of Change: A New Administration for a New European Union?', in: Eipascope 3: 20-25.

Cyert, R. M. and March J. G. (1992) A Behavioral Theory of the Firm, Oxford: Oxford University Press.

Delors, J. (1987) "Introduction of the Commission's Programme for 1987", Supplement of the Bulletin of the European Communities 87/1.

Derthick, M. (1970) The Influence of Federal Grants. Public Assistance in Massachusetts, Cambridge, Massachusetts: Harvard University Press.

Derthick, M. (1972) New Towns In-town: Why a Federal Program Failed, Urban Institute, Washington DC.

Dimitrakopoulos, D. G. (ed.) (2004) The Changing European Commission, Manchester: Manchester University Press.

Docksey, C. and Williams, K. (1994). 'The Commission and the Execution of Community Policy', in G. Edwards and D. Spence (eds.), "The European Commission”, London: Cartermill, pp. 125-54. 
Duìna, F. (1997) 'Explaining Legal Implementation in the European Union', International Journal of the Sociology of Law 25: 155-79.

Egeberg, M. (1996) 'Organization and Nationality in the European Commission Services', Public Administration 74(4): 721-35.

Egberg, M. (2003) 'The European Commission', in M. Cini (ed.), European Union Politics, Oxford: Oxford University Press, pp. 131-145.

Egeberg, M. (2004) 'An organisational approach to European integration: outline of a complementary perspective', European Journal of Political Research 43: 199-219.

Egeberg, M. (2005) 'Europe's executive branch of government in the melting pot - an overview'. Paper presented at the CONNEX RG1 Conference at the University of Oslo 27-28 May, 2005.

Falkner G., Treib, O., Hartlapp, M., Leiber, S. (2004) 'Non-Compliance with EU Directives in the Member States: Opposition through the Backdoor?', West European Politics 27(3): 452-473.

Franchino, F. (2000) 'Control of the Commission's Executive Functions: Uncertainty, Conflict and Decision Rules', European Union Politics 1: 63-92.

From, J. and Stava. P. (1993) 'Implementation of Community Law: The Last Stronghold of National Control?', in S. S. Andersen and K. A. Eliassen (eds.), Making Policy in Europe. The Europeification of National Policy-Making, London: Sage, pp. 55-67.

Haas, P. M. (1998) 'Compliance with EU Directives: Insights from International Relations and Comparative Politics', Journal of European Public Policy 5, 17-37.

Hix, S. (2005) The Political System of the European Union, 2nd Edition, London: Palgrave.

Holmström, B. (1979) 'Moral Hazard and Observability', Bell Journal of Economics 10(1): 74-91.

Holzinger, K., Knill, C., Schäfer, A. (2003) 'Steuerungswandel in der europäischen Umweltpolitik?', in K. Holzinger, C. Knill and D. Lehmkuhl (eds.), Politische Steuerung im Wandel. Der Einfluss von Ideen und Problemstrukturen. Opladen: Leske und Budrich.

Hooghe, L. (1996a) Cohesion Policy and European Integration: Building Multi-Level Governance, Oxford: Oxford University Press.

Hooghe, L. (1996b) 'Building a Europe with the Regions: The Changing Role of the European Commission', in

L. Hooghe (ed.), Cohesion Policy and European Integration: Building Multi-Level Governance, Oxford: Oxford University Press, pp. 89-125.

Hooghe, L. (1997) 'A House with Differing Views: The European Commission and Cohesion Policy', in N. Nugent (ed.), At the Heart of the Union. Studies of the European Commission, New York: St. Martin's, pp. 89- 108.

Hooghe, L. (2001) The European Commission and the Integration of Europe. Images of Governance. Cambridge: Cambridge University Press.

Hooghe, L. and Keating, M. (1994) 'The Politics of EU Regional Policy', Journal of European Public Policy 1(3): 367-93.

Hooghe, L. and Marks, G. (2001) Multi-Level Governance and European Integration. New York and Oxford: Rowman \& Littlefield.

Ingram, H. (1990) 'Implementation: A Review and Suggested Framework', in N. Lyn and A. Wildavsky (eds.), Public Administration. The State of the Discipline, Chatham, New Jersey: Chatham House Publishers, pp. 462-481.

Kassim, H. (2004) 'A Historic Accomplishment. The Prodi Commission and Administrative Reform', in D. G. Dimitrakopoulos (ed), The Changing European Commission, Manchester: Manchester University Press, pp. 33-62.

Knill, C. (2006) ,Implementation', in: Richardson, J. (ed.), European Union, Power and Policy-Making, 3 edition, New York: Routledge, 351-375.

Knill, C. (2003). Europäische Umweltpolitik. Opladen: Leske und Budrich. 
Knill, C. and Lenschow, A. (eds.) (2000) Implementing EU Environmental Policy: New Directions and Old Problems. Manchester: Manchester University Press.

Laffan, B. (1997) 'From Policy Entrepreneur to Policy Manager: The Challenge Facing the European Commission', Journal of European Public Policy 4(3): 422-38.

Lampinen, R. and Uusikylä, P. (1998) 'Implementation Deficit - Why Member States do not comply with EU Directives', Scandinavian Political Studies, 21(3): 231-251.

Laumann, E. O., Galaskiewicz, J. and Marsden P. V. (1987) 'Community Structure as Interorganizational Linkages', Annual Review of Sociology 4: 455-84.

Laumann, E. O. and Knoke, D. (1987) The Organizational State. Social Choice in National Policy Domains. Wisconsin: University of Wisconsin Press.

Lenschow, A. (1999) 'Transformation in European Environmental Governance', in B. Kohler-Koch and R. Eising (eds.), The Transformation of Governance in the European Union. London: Routledge, pp. 39-60.

Levinthal, D. (1988) 'A Survey of Agency Models of Organizations', Journal of Economic Behavior and Organization 9: 153-85.

Levy, R. (1997) 'Managing the Managers: The Commission's Role in the Implementation of Spending Programmes', in N. Nugent (ed.), At the Heart of the Union. Studies of the European Commission, New York: St. Martin's, pp. 203-25.

Levy, R. (2003a) 'Critical success factors in public management reform: the case of the European Commission', International Review of Administrative Sciences 69: 553-566.

Levy, R. (2003b) 'Confused Expectations: Decentralizing the Management of EU Programmes', Public Money and Management, 23(2): 83-92.

Majone, G. (2002) 'The European Commission: the limits of centralization and the perils of parliamentarization', Governance 15(3): 375-392.

Marks, G. (1992) 'Structural Policy in the European Community', in A. M. Sbragia (ed.), Euro-Politics. Institutions and Policymaking in the 'New' European Community, Washington: Brookings Institution, pp: 191- 224.

Marks, G. (1993) 'Structural Policy and Multilevel Governance in the EC', in A. W. Cafruny and G. G. Rosenthal (eds.), The State of the European Community. The Maastricht Debates and Beyond, Boulder: Lynne Rienner Longman, pp. 391-411.

Marks, G. (1996a) 'Decision Making in Cohesion Policy: Describing and Explaining Variation', in L. Hooghe (ed.), Cohesion Policy and European Integration: Building Multi-Level Governance, Oxford: Oxford University Press.

Marks, G. (1996b) 'Politikmuster und Einflußlogik in der Strukturpolitik', in M. Jachtenfuchs and B. Kohler-Koch (eds.) Europäische Integration, Opladen: Leske \& Budrich, pp. 313-43.

Marks, G., Hooghe L. and Blank, K. (1996) 'European Integration From the 1980s: State-Centric V. Multi-Level Governance', Journal of Common Market Studies 34(3): 341-78.

McCubbins, M D. and Schwartz, T. (1984) 'Congressional Oversight Overlooked: Police Patrols Versus Fire Alarms', American Journal of Political Science 28(1): 165-79.

McCubbins, M D., Noll R. G. and Weingast, B. R. (1989) 'Structure and Process, Politics and Policy: Administrative Arrangements and the Political Control of Agencies', Virginia Law Review 75: 431-82.

Mendrinou, M. (1996) 'Non-Compliance and the European Commission's Role in Integration', Journal of European Public Policy, 3: 1-22.

Metcalfe, L. (1992) 'After 1992: Can the Commission Manage Europe?'Australian Journal for Public Administration 51 (1): 117-30.

Metcalfe, L. (1996) 'The European Commission as a Network Organization', The Journal of Federalism 26(4): 43-62.

Metcalfe, L. (2000) 'Reforming the European Commission: Will Organizational Efficiency Produce Effective Governance?', Journal of Common Market Studies 38(5): 817-841. 
Metcalfe, L. (2001) 'Reforming European governance: old problems or new principles?', International Review of Administrative Sciences 67: 415-443.

Moe, T. M. (1984) 'The New Economics of Organization', American Journal of Political Science 28(4):739-77.

Noel, E. (1973) 'The Commission's Power of Initiative', Common Market Law Review 10: 123-125.

Nugent, N. (1994) The Government and Politics of the European Union. Basingstoke: Macmillan.

Nugent, N. (1995) 'The Leadership Capacity of the European Commission', Journal of European Public Policy 2(4): 603-23.

Nugent, N. (1997) 'At the Heart of the Union', in N. Nugent (ed.), At the Heart of the Union. Studies of the European Commission. New York: St. Martin's, pp. 1-26.

O'Toole, L.R. Jr. (2000) 'Research on Policy Implementation: Assessments and Prospects'Journal of Public Administration Research \& Theory, 10(2): 263-289.

Peters, G. B. (1997) 'The Commission and Implementation in the European Union: Is There a Implementation Deficit and Why?', in N. Nugent (ed.), At the Heart of the Union. Studies of the European Commission, Basingstoke: Macmillan, pp. 187-202.

Peterson, J. (1999) 'The Santer Era: the European Commission in Normative, Historical and Theoretical Perspective', Journal of European Public Policy 6(1): 46-65.

Pfeffer, J. (1982), Organizations and Organization Theory. London: Pitman.

Pfeffer, J. and Salancik, G. R. (1978) The External Control of Organizations: A Resource Dependence Perspective. New York: Harper and Row.

Pollack, M. A. (1995) 'Regional Actors in an Intergovernmental Play: The Making and Implementation of EC Structural Policy', in C. Rhodes and S. Mazey (eds.), The State of the European Union. Building a European Polity?, Boulder: Lynne Rienner Longman, pp. 361-90.

Pollack, M. A. (1997) 'Delegation, Agency and Agenda Setting in the European Community', International Organization 51(1): 99-134.

Pollack, M. A. (2003) The Engines of European Integration: Delegation Agency and Agenda Setting in the EU. Oxford: OUP.

Pressmann, J. L. and Wildavsky, A. B. (1973) Implementation. How Great Expectations in Washington are Dashed in Oakland, Berkeley: University of California Press.

Prodi, R. (1999a) Speech delivered to the European Parliament, 13 April 1999, Strasbourg.

Prodi, R. (1999b) Speech delivered to the European Parliament, 4 May 1999, Strasbourg.

Prodi, R. (2000) Speech delivered to the European Parliament introducing the Commission's 'White Paper on Reform', 1 March 2000, Brussels.

Puchala, D. J. (1975) 'Domestic Politics and Regional Harmonisation in the European Communities', World Politics 27(4): 496-520.

Rhodes, R.A.W. (1986a) European Policy-Making, Implementation and Subcentral Governments: A Survey, Maastricht: European Institute of Public Administration.

Rhodes, R.A.W. (1986b): 'Power Dependence. Theories of central-local relations: A critical reassessment', in: Goldsmith, M. (ed.) New Research in Central Local Relations, Aldershot, Gower: 1-33.

Rhodes, R.A.W., Bache, I. and Georges, S. (1996) 'Policy Networks and Policy-Making in the European Union: A Critical Appraisal', in: Hooghe, L. (ed.) Cohesion Policy and European Integration: Building Multi-Level Governance, Oxford: Oxford University Press, pp. 367-387.

Sabatier, P. A. (1993) 'Top-Down and Bottom-Up Approaches to Implementation Research', in: M. Hill (ed.): The Public Policy Process: A Reader, London, pp. 266-293.

Sabatier, P. and Mazmanian, D. (1979) 'Conditions of Successful Policy Implementation', Policy Analysis, February 1979: 401-504.

Santer, J. (1998) 'Speech given to the European Parliament 2 December 1998 in Brussels', 
http://europa.eu.int/abc/doc/off/bull/en/9812/p109001.htm last access 26 September 2005.

Scharpf, F.W., Reissert, B. and Schnabel F. (1976) Politikverflechtung: Theorie und Empirie des kooperativen Föderalismus in der Bundesrepublik, Kronberg/Taunus: Scriptor Verlag.

Schmidt, S. K. (2000) 'Only an Agenda Setter? The European Commission's Power over the Council of Ministers', European Union Politics 1 (1): 37-61.

Schmidt, S. K. (2004) 'The European Commission's powers in shaping European policies', in D. G. Dimitrakopoulos (ed), The Changing European Commission, Manchester: Manchester University Press, pp. 105-120.

Smith, A. (ed.) (2004) Politics and the European Commission. Actors, Interdependence, and Legitimacy, London/New York: Routledge.

Smith, M.P. (1997) 'The Commission Made Me Do It: The European Commission as a Strategic Asset in Domestic Politics', in N. Nugent (ed.), At the Heart of the Union. Studies of the European Commission, London: Macmillan, pp. 167-186.

Smith, M.P. (1998) 'Autonomy by the Rules: The European Commission and the Development of State Aid Policy', Journal of Common Market Studies 36: 55-78.

Smyrl, M. E. (1998) 'When (and How) Do the Commission's Preferences Matter?', Journal of Common Market Studies 36(1): 79-99.

Spence, D.B. (2000) 'Plus ca change, plus c'est la même chose? Attempting to Reform the European Commission', Journal of European Public Policy 7: 1-25.

Stoker, R.P. (1991). Reluctant Partners. Implementing Federal Policy, Pittsburgh: University of Pittsburgh Press.

Tallberg, J. (1999) Making States Comply. The European Commission, the European Court of Justice and the Enforcement of the Internal Market, Lund Political Studies 109: Lund University.

Tallberg, J. (2002a) 'Delegation to Supranational Institutions: Why, How, and What Consequences?', West European Politics 25(1): 23-46.

Tallberg, J. (2002b) 'Paths to Compliance: Enforcement, Management, and the European Union', International Organization 56(3): 609-643.

Tömmel, I (2003) 'Transformation politischer Steuerung im Rahmen distributiver Politiken der Europäischen Union', in K. Holzinger, C. Knill and D. Lehmkuhl (eds.), Politische Steuerung im Wandel: Der Einfluss von Ideen und Problemstrukturen, Leske \& Budrich, pp. 133-149.

Tsebelis, G. and Kreppel A. (1998) 'The History of Conditional Agenda-Setting in European Institutions', European Journal of Political Research 33(1): 41-71.

\section{Documents}

Bundesministerium für Wirtschaft (1996) 'Thesen zur Reform der EU-Strukturfonds', (Papier der Arbeitsebene),

3. Fassung, Bonn: unpublished manuscript, BMWi, Stand 30.10.1996.

Bundesministerium für Wirtschaft (1997) 'Stellungnahmeentwurf zur Agenda 2000—Kohäsionspolitik der Gemeinschaft', Bonn: unpublished manuscript, BMWi, 7 August 1997.

Bundesregierung (1998) 'Europastaatssekretäre. Protokoll der Sitzung der Europa-Staatssekretäre am 1. April 1998', Bonn: unpublished manuscript.

Commission of the European Communities (1988) 'Programme of the Commission for 1988 -Address by Jacques Delors, President of the Commission, to the European Parliament', Strasbourg, 20 January 1988, Bulletin of the European Communities, Supplement 1/1988. Luxembourg: Office for Official Publications of the EC.

Commission of the European Communities (1989) 'Guide to the Reform of the Community's Structural Funds', Luxembourg: Office for Official Publications of the EC.

Commission of the European Communities (1992) 'Communication From the Commission: An Open and Structured Dialogue Between the Commission and Special Interest Groups', SEC (92) 
2272 Final, Brussels, 2 December 1992. Luxembourg: Office for Official Publications of the EC.

Commission of the European Communities (1997) 'Commission Regulation (EC) No 2064/97 of 15 October 1997 Establishing Detailed Arrangements for the Implementation of Council Regulation (EEC) No 4253/88 As Regards the Financial Control by Member States of Operations Co-Financed by the Structural Funds, OJ L 290, 23 October 1997', Luxembourg: Office for Official Publications of the EC.

Commission of the European Communities (1998) 'Evaluation Review 1998 (DG XIX)', Luxembourg: Office for Official Publications of the EC.

Commission of the European Communities (2005) 'Mitteilung der Kommission. Die Kohäsionspolitik im Dienste von Wachstum und Beschäftigung. Strategische Leitlinien der Gemeinschaft für den Zeitraum 20072013', Brussels 5 of July 2005, COM (2005) 299.

Community Support Framework, CSF, Commission of the European Communities. Community Support Framework Germany 1994-1999, Objective 3: Combating Long-Term Unemployment and Facilitating the Integration into Working Life of Young People and of Persons Exposed to Exclusion From the Labour Market. Luxembourg: Office for Official Publications of the EC, 1995a.

Community Support Framework, CSF, Commission of the European Communities (1995a) 'Gemeinschaftliches Förderkonzept 1994-1999 Deutschland. Ziel Nr. 3: Bekämpfung der Langzeitarbeitslosigkeit und Erleichterung der Eingliederung der Jugendlichen und der vom Ausschluß aus dem Arbeitsmarkt bedrohten Personen in das Erwerbsleben', Luxembourg: Office for Official Publications of the EC.

Community Support Framework, CSF, Commission of the European Communities (1995b) 'Gemeinschaftlicher Förderkonzept 1994-1999 Deutschland. Neue Länder: Ziel 1: Förderung der Entwicklung und der Strukturellen Anpassung der Regionen mit Entwicklungsrückstand'Luxembourg: Office for Official Publications of the EC.

Council (1998a) 'Framework Regulation', Council Regulation (EEC) No. 2052 of 24 June 1988 on the Tasks of the Structural Funds and Their Effectiveness and on Co-ordination of Their Activities Between Themselves and With the Preparations of the European Investment Bank and Other Existing Financial Instruments, OJ L 185, 15 July 1988. Luxembourg: Office for Official Publications of the EC.

Council (1988b) 'Co-ordination Regulation'Council Regulation (EEC) No. 4253/88 of 19 December Laying Down Provisions for Implementing Regulation (EEC) No. 2052 As Regards Coordination of the Activities of the Different Structural Funds Between Themselves and With the Operations of the European Investment Bank and the Other Existing Financial Instruments, OJ L 374, 31 December 1988. Luxembourg: Office for Official Publications of the EC.

Council (1993) 'New Co-ordination Regulation'Council Regulation (EEC) No. 2082/93 of 20 July 1993 Amending Regulation (EEC) No. 4253/88 Laying Down Provisions for Implementing Regulation (EEC) No. 2052/88 As Regards the Co-ordination of the Activities of the Different Structural Funds Between Themselves and With the Operations of The European Investment Bank and the Other Existing Financial Instruments, OJ L 193, 31 July 1993. Luxembourg: Office for Official Publications of the EC.

Court of Auditors of the European Communities (1979) 'Annual Report Concerning the Financial Year 1978 Accompanied by the Institutions' Replies', OJ C 326, 24 November 1979. Luxembourg: Office for Official Publications of the EC.

Court of Auditors of the European Communities (1992) 'Annual Report Concerning the Financial Year 1991 Accompanied by the Institutions' Replies', OJ C 330, 15 December 1992. Luxembourg: Office for Official Publications of the EC.

Court of Auditors of the European Communities (1993) 'Annual Report Concerning the Financial Year 1992 Accompanied by the Institutions' Replies', OJ C 309, 16 September 1993. Luxembourg: Office for Official Publications of the EC.

Court of Auditors of the European Communities (1994) 'Annual Report Concerning the Financial Year 1993 Accompanied by the Institutions' Replies', OJ C 327, 24 November 1994. Luxembourg: Office for Official Publications of the EC. 


\section{Contact}

Prof. Dr. Christoph Knill

Chair of Comparative Public Policy and Administration

Box D 91

D-78457 Konstanz

Germany

Phone ++497531885597

Fax ++ 497531882381

christoph.knill@uni-konstanz.de

University of Konstanz

(7) www.uni-konstanz.de

Department of Politics and Management

(7) www.uni-konstanz.de/sektionen/polver

Chair of Comparative Public Policy and Administration

(7) www.uni-konstanz.de/FuF/Verwiss/knill

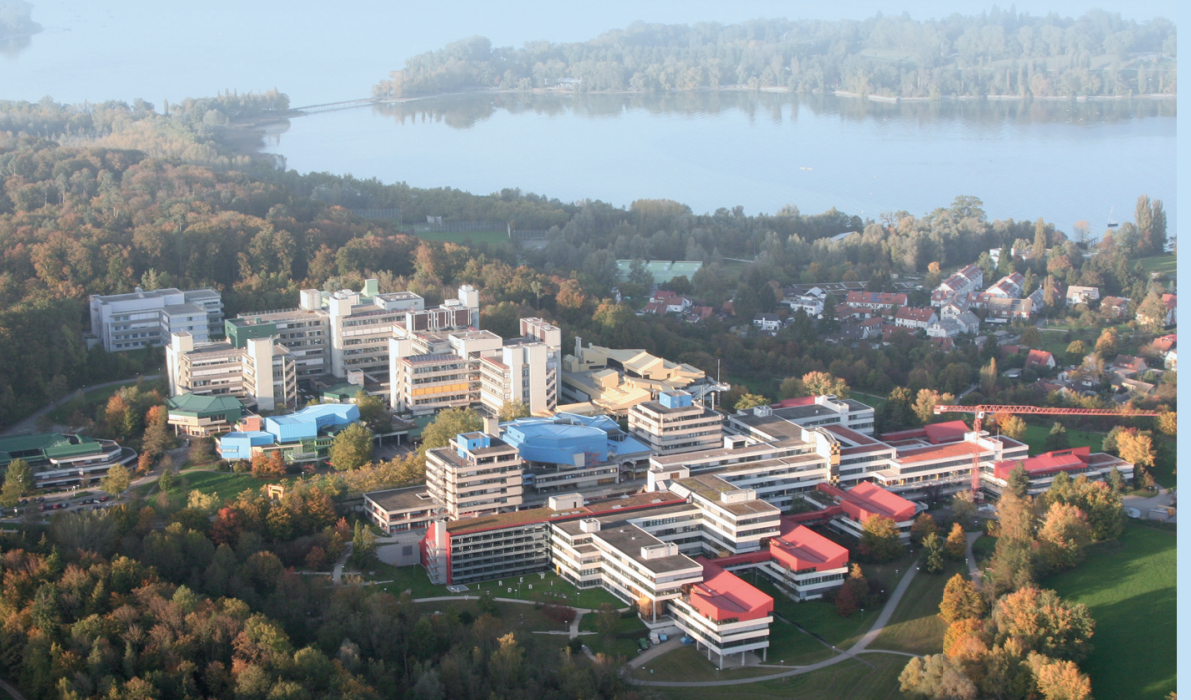

